\title{
2. The Tellus airborne geophysical surveys and results
}

\author{
James Hodgson $^{1}$ And Mike Young ${ }^{2}$
}

How to cite this chapter:

Hodgson, J.A. and Young, M.E., 2016 'The Tellus airborne geophysical surveys and results' in M.E. Young (ed.), Unearthed: impacts of the Tellus surveys of the north of Ireland. Dublin. Royal Irish Academy.

DOI:10.3318/ 978-1-908996-88-6.ch2
The Tellus airborne geophysical survey of Northern Ireland was flown in 2005-6 and the Tellus Border survey of the six most northern counties of the Republic of Ireland in 2011-2. Together the two surveys covered a region of approximately $25,000 \mathrm{~km}^{2}$, or $30 \%$ of the land surface of the island of Ireland. Three parameters were measured and mapped: magnetic field, electrical conductivity and gamma radiation. These parameters vary significantly between the different rocks found in this region, and data from these surveys have proved valuable in supporting geological mapping, environmental monitoring and mineral prospecting. This chapter describes the operations and summarises the results and some of the geoscience research that followed.

\section{INTRODUCTION}

All rocks have several different physical properties that may be measured directly or inferred indirectly from the physical signals, or fields, that they produce. These measurements can be analysed and modelled in terms of the depth, extent and physical character of the rock formation that bears these properties. These fields can be measured underground, on the ground surface or in the air; surveys made with aircraft enable the efficient and rapid collection of regularly spaced measurements at an even height above the ground and away from the influence of man-made 'noise'. The techniques are well established and many of the systems used today result from continued development and refinement of innovations made originally during the Second World War.

The principal physical properties of rocks exploited in geological exploration, research and mapping include the velocity of sound, density, magnetisation, electrical properties and radioactivity. Of these, from an aircraft we can readily observe and record variations of the magnetic field, electrical conductivity and gamma radiation of the rocks beneath the flight path.

On an airborne geophysical survey the aircraft flies along a network of pre-planned parallel lines, typically at a nominal height of between 30 and $500 \mathrm{~m}$ above ground level. Digital readings of the various parameters are made automatically at appropriate intervals,

Geological Survey of Ireland, Dublin.

${ }^{2}$ Geological Survey of Northern Ireland, Belfast. 
which may vary from one tenth of a second (for the magnetic field) to up to one second (for gamma radiation), equivalent to measurements at intervals of approximately $6 \mathrm{~m}$ and $60 \mathrm{~m}$ respectively. The aircraft's position is continuously recorded by a Global Positioning System (GPS). Simultaneously the aircraft's height is recorded above ground by a laser or radar rangefinder and above sea level by a barometric altimeter.

The data are recorded digitally and transferred for processing after each flight. After correction for various extraneous effects and standardisation, the results are contoured and presented typically as coloured imagery, maps or cross-sections.

\section{Magnetic Field}

With modern airborne magnetometers the strength of the magnetic field of the Earth can be measured and mapped with a sensitivity of about one part in five million. These variations in the measured magnetic field indicate variations in the nature and geometry of magnetised rock below the aircraft. The patterns of the magnetic map show both major geological structures deep within the Earth and the shallower effects of magnetised rocks nearer the surface. In the north of Ireland, relatively highly magnetised rocks include the Antrim Lava Group, Palaeocene dykes and intrusive centres of the Mournes and Slieve Gullion, and older igneous and metamorphic rocks.

\section{EleCtRICAL CONDUCTIVITY}

The electrical conductivity of rocks and soils varies according to changes in porosity, salinity, saturation and clay content. Variations in electrical conductivity indicate lithological changes within and between formations. Extended conductors such as graphite bearing beds, faults and saline areas may show prominent electrical anomalies. Man-made features, notably roads, power-lines and fences, are often clearly distinguished and other anthropogenic effects such as ground contamination may produce more subtle conductivity anomalies. Electrically conductive rocks include the Oligocene clays and Triassic sediments to the south and south-west of Lough Neagh and other clay-rich sedimentary rock and fault zones, notably in the south-west of the surveyed area. It is sometimes convenient to image and display resistivity, the reciprocal of conductivity. Electrically resistive formations include the hard, metamorphic Dalradian rocks of the north-west and the Palaeocene dykes and intrusive centres.

\section{NatURAL RADIOACTIVITY}

All rocks and soils contain very small amounts of radioactive elements, which produce gamma radiation detectable at the survey altitude. Terrestrial radiation comes from the isotopes of uranium, thorium and potassium and the proportions of these vary among different rock types. Therefore mapping the natural radioactivity helps to differentiate rock and soil types. Radon gas, a naturally occurring carcinogen that can find its way into homes, is a product of the radioactive decay of uranium in the ground and its distribution 
can be modelled from the collected data. Man-made radioactivity, from nuclear fission, is also detectable; caesium-137, with a half-life of 30 years, is routinely mapped as most other fission isotopes are relatively short-lived. Generally higher radioactivity characterises acid igneous rocks, most notably the Palaeocene intrusions of counties Down and Louth, some sedimentary beds, particularly shales in the south-west, the Lower Palaeozoic DownLongford Terrane, and parts of the Dalradian metasediments.

\section{Previous Regional geophysical SURVEys in Ireland}

Numerous airborne geophysical surveys have been made in Ireland since the 1950s, both national mapping programmes by government and more targeted surveys by mining companies.

The last national regional airborne survey of Northern Ireland was flown in 1959. This was a magnetic survey flown at a height of $305 \mathrm{~m}$ above ground along lines spaced $2000 \mathrm{~m}$ apart. Because of the high survey altitude and wide line spacing the resolution was limited, but the results outlined the principal features of the regional geology of Northern Ireland and provided the basis for interpreting its broad structural setting. These surveys and results, with the complementary gravity data, were interpreted by Carruthers et al. (1999), whose work was reviewed and extended by Reay (2004).

In the Republic of Ireland a national airborne magnetometer survey of eastern, central and western parts, covering most of the Republic, was flown between 1979 and 1981. The objectives were to outline variations in the crystalline basement and sedimentary cover, to improve knowledge of the regional geological structure and to locate areas of potential mineralisation. Survey lines were flown in blocks with different specifications; the line spacing varied between 1 and $2 \mathrm{~km}$ and survey altitudes between 200 and $450 \mathrm{~m}$.

Numerous airborne geophysical surveys have been carried out since 1995 by mineral companies exploring for base metals, predominantly within the Irish Midlands/Lower Carboniferous region (Dardis, 2002). These were mostly magnetic surveys, with some incorporating transient electromagnetic (TEM) and radiometric measurements. Line spacing was usually 75-200 m. The data are available from the Exploration and Mining Division (EMD) of the Department of Communications, Energy and Natural Resources and from the Geological Survey of Northern Ireland (GSNI).

Airborne data are usefully complemented by measurement of the Earth's gravity field, in the air or on the ground. Such measurements, which are complementary to magnetic data, have been previously collected over most of Ireland. The first regional gravity survey of Ireland was conducted in 1950 by Dublin Institute for Advanced Studies (DIAS) and this work has continued with new data added to the national survey over the years. There are now more than 23,000 stations across the Republic of Ireland, with an accuracy of 0.2 mGal. Gravity surveys of Northern Ireland have been carried out by the BGS in several operations since the 1950s, including during the Tellus Project, with a total of approximately 11,000 stations observed across the province. 
into the Tellus Border results. The aircraft was based variously at Newtownards, Enniskillen and Londonderry.

The Tellus Border survey was flown between October 2011 and July 2012 over the areas shown in Fig. 2.1. The area comprises counties Sligo, Leitrim, Cavan, Monaghan and Louth and parts of counties Donegal, Mayo, Roscommon, Longford, Westmeath and Meath. 57,682 line-km was flown, at a nominal height above ground of $59 \mathrm{~m}$ in rural areas and $240 \mathrm{~m}$ over urban zones. As the Tellus survey of 2005/6 had extended into the Republic of Ireland by up to $2 \mathrm{~km}$ to provide an overlap for future surveys, no low-flying within Northern Ireland was required to link the two surveys. The survey team was based at St Angelo's Airport in Enniskillen, County Fermanagh.

The survey operations were preceded and accompanied by intense public communications programmes to alleviate any public concerns. Both these successful programmes received awards from professional public relations bodies and exemplify how the use of modern communications and transparency can raise positive public interest in government science.

\section{Table 2.1. Survey Design and system Specifications}

\begin{tabular}{l|c|c} 
& Tellus, 2005-6 & Tellus Border, 2011-12 \\
\hline Survey line spacing & \multicolumn{2}{|c}{$200 \mathrm{~m}$} \\
\hline Survey line direction & \multicolumn{2}{|c}{$345^{\circ}$} \\
\hline Tie line spacing & $\begin{array}{c}\text { 2005: } 2 \mathrm{~km} \text { (part only) } \\
\text { 2006: none }\end{array}$ & $2 \mathrm{~km}$ \\
\hline Tie line direction & \multicolumn{2}{|c}{$75^{\circ}$} \\
\hline Nominal survey altitude (rural) & $56 \mathrm{~m}$ & $59 \mathrm{~m}$ \\
\hline Nominal survey altitude (other) & $244 \mathrm{~m}$ & $240 \mathrm{~m}$ \\
\hline Typical survey speed & $70 \mathrm{~m} / \mathrm{s}$ & $60 \mathrm{~m} / \mathrm{s}$ \\
\hline Magnetic sampling & \multicolumn{2}{|c}{$0.1 \mathrm{~s}$} \\
\hline Electromagnetic sampling & $0.25 \mathrm{~s}$ & $0.1 \mathrm{~s}$ \\
\hline Radiometric sampling & \multicolumn{2}{|c}{$1.0 \mathrm{~s}$} \\
\hline GPS positioning sampling & \multicolumn{2}{|c}{$0.0 \mathrm{~s}$} \\
\hline Magnetic/GPS base station sampling & \multicolumn{2}{|c}{$0.39608 \mathrm{MeV}$} \\
\hline Radiometric total energy range & $0.912,3.005,11.962 \& 24.510 \mathrm{kHz}$
\end{tabular}




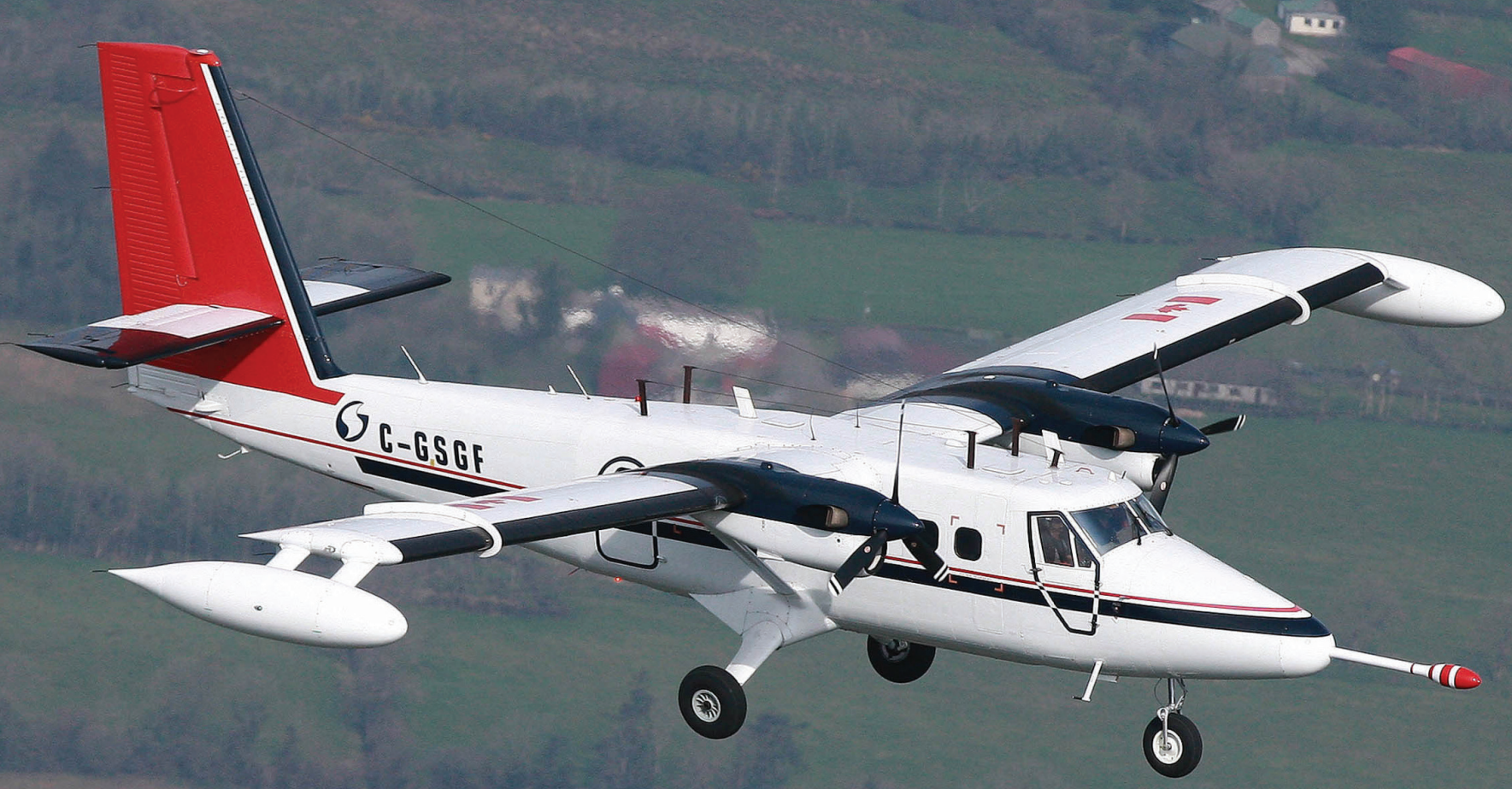

\section{SURVEY SPECIFICATIONS}

The same aircraft was used for both operations, a specially adapted De Havilland DHC-6 Twin Otter. The first Tellus survey was flown by the Joint Airborne-geophysical Capability, a partnership of the British Geological Survey (BGS) and the Geological Survey of Finland (GTK). GTK provided pilots with great experience of flying geophysical surveys at low altitudes and an aircraft and equipment that had flown many thousands of kilometres of low-level environmental mapping surveys, in Finland and abroad. Subsequently the aircraft was purchased by a leading international specialist contractor, Sander Geophysics Ltd (SGL) of Ottawa, Canada, which undertook the Tellus Border survey.

The Twin Otter aircraft is an all-metal, fixed-wing, twin-engine, short take-off and landing aircraft (Fig. 2.2). Survey speeds of the aircraft were approximately 120 knots (60 $\mathrm{m} / \mathrm{s}$ ); other survey parameters are shown in Table 2.1.

The Twin Otter was equipped with airborne magnetic, radiometric and frequencydomain electromagnetic (FEM) systems as described by Hautaniemi et al. (2005) and Leväniemi et al. (2009) and summarised in Table 2.2. The aircraft housed two magnetometers, one attached to the nose and one in the left wing tip pod. The four-frequency EM transmitter coil (two-frequency only in 2005) was housed in the right wing tip pod and the receiver coil in the left wing tip pod. The gamma-ray spectrometer crystal detectors were housed in the rear of the cabin.
Figure 2.2. De Havilland Twin Otter survey aircraft. The wing tips contain the electromagnetic transmitter and receiver coils and one magnetometer sensor. The nose-cone houses the second magnetometer sensor. 


\section{Table 2.2. Geophysical instrument SPECifications}

\begin{tabular}{|c|c|}
\hline Survey method & Equipment used \\
\hline Magnetometer & $\begin{array}{l}\text { Aircraft: two Scintrex CS-2 caesium-vapour sensors, mounted in } \\
\text { nose-cone and one wing tip } \\
\text { Base stations: two Geometrics G-822A }\end{array}$ \\
\hline EM system & $\begin{array}{l}\text { JAC AEM-05, four frequency system with wing-tip-mounted } \\
\text { transmitter and receiver coils }\end{array}$ \\
\hline Gamma-ray spectrometer & $\begin{array}{l}\text { Exploranium GR-820 gamma-ray spectrometer, } 256 \text { channels, } \\
\text { self-calibrating, } 33.6 \text { litres downward, } 8.4 \text { litres upward looking } \\
\text { NaI crystals, with integral pressure and temperature sensors }\end{array}$ \\
\hline
\end{tabular}

\section{DATA PROCESSING AND PRESENTATION}

\section{Magnetic field}

The magnetic field data, which were collected from two sensors, were first screened for electronic spikes and corrected for the diurnal variation of the magnetic field, using reference data from base station magnetometers positioned in the survey area. Tellus data were subject to filtering to remove man-made magnetic noise (Lahti et al., 2007). Tellus Border data were subject to a height correction to allow for significant varying survey height, particularly in areas where the vertical gradient and magnetic intensity were high. Levelling of the two surveys was accomplished by different processes; the Tellus data were levelled by a statistical process (White and Beamish, 2015) while the Tellus Border data were levelled by the conventional process that minimises the differences between measurements at the intersections of survey lines and orthogonal 'tie-lines'.

The amplitude of the Earth's large-scale magnetic field, the International Geomagnetic Reference Field, was also removed from the data, the final result being known as the Total Magnetic Intensity Anomaly (TMI), the magnetic signal from relatively local sources. The TMI is usually presented in the form of a coloured image, with warmer colours denoting relatively high values. Features or anomalies of the TMI may be judiciously enhanced or suppressed by digital filtering using a range of numerical processes, as presented by Chacksfield (2007).

\section{Electromagnetic (EM) data}

EM data were recorded at four different frequencies - 912, 3005, 11,962 and 24,510 Hz - at a sampling rate of $40 \mathrm{~Hz}$, later reduced to $10 \mathrm{~Hz}$ in the processing. EM data recorded at the receiver coil were in-phase and out-of-phase electromagnetic responses to primary signals sent into the ground from a transmitter coil on the opposite wingtip. After removal of spikes and noise, system-specific calibrations and adjustments for electronic drift were applied, followed by survey line/tie-line levelling. Corrected in-phase and out-of-phase 


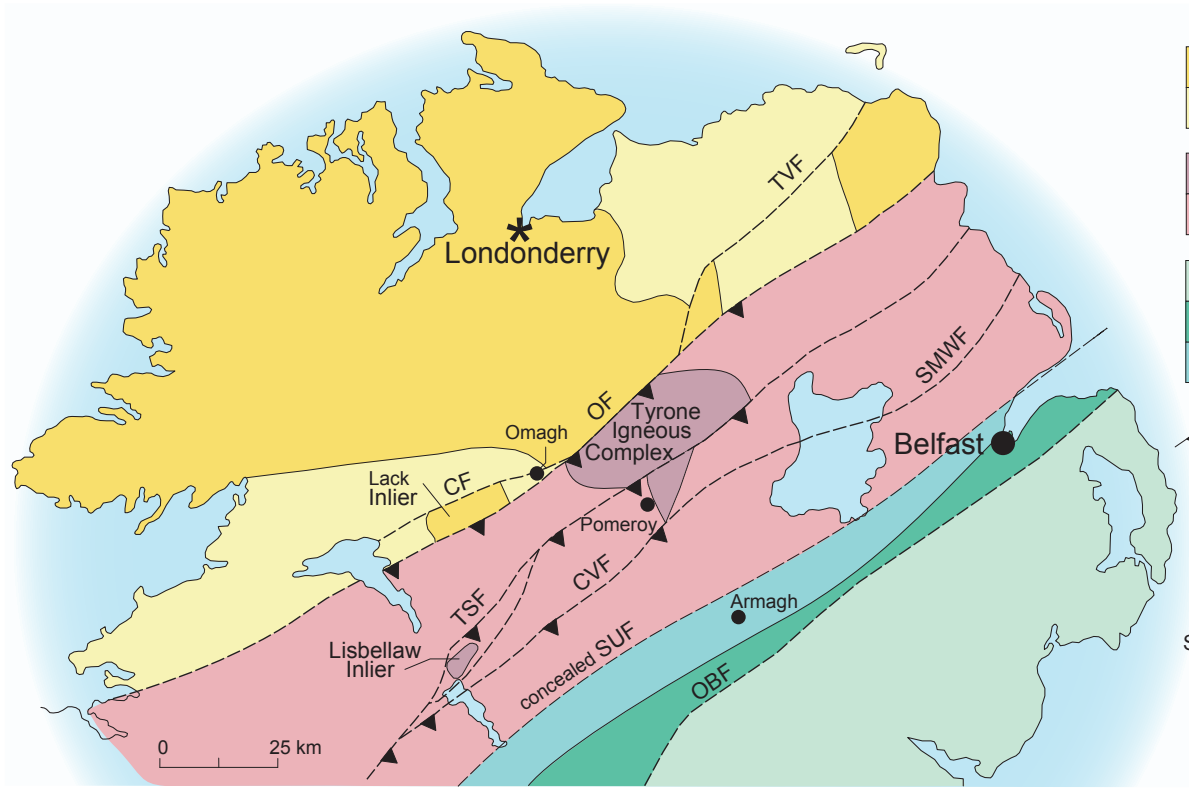

(quadrature) signals were converted into apparent ground conductivity using a standard process and presented as coloured imagery.

\section{Gamma radiation (radiometric) data}

The gamma-ray detector system comprised a large set of sodium iodide crystal detectors, which emit a flash of light on the passage of a gamma-ray. The intensity and energy of scintillations is continuously recorded and integrated over one second intervals. Gamma radiation comes not only from the rocks beneath but also as cosmic rays from space, from radon gas in the air and from the aircraft itself. These extraneous signals are separated out in the data processing sequence, in which corrections for varying height above ground are also made.

Gamma radiation comprises signals of varying energies and the various radioactive isotopes of uranium, thorium and potassium can be distinguished by the energy of their emissions. Separating these signals is the function of the 256 channel radiometric spectrometer, which was calibrated prior to survey over pads dosed with known amounts of uranium, potassium and thorium. Processing of these data was undertaken according to methods set out by the International Atomic Energy Agency. After processing and conversion to equivalent concentrations, based on the pad calibrations, the values of equivalent uranium, thorium and potassium are presented in coloured imagery. These data may also effectively be displayed as ratios (for example, uranium/potassium) or in a ternary format where the three isotopes are represented collectively, presentations that serve to identify anomalous features.
Figure 2.3. Basement terranes of the north of Ireland (Mitchell, 2004). 


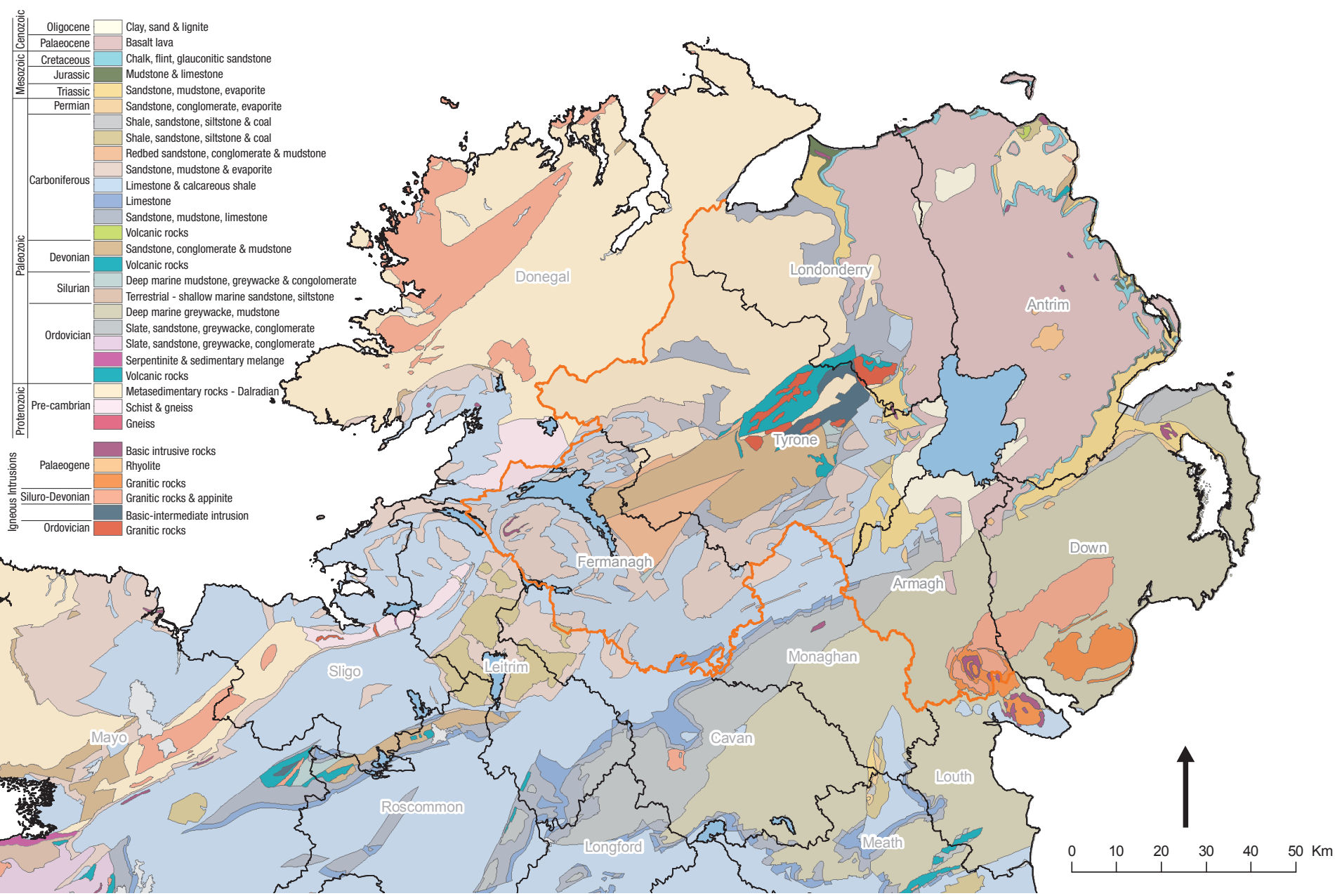

Figure 2.4. From the $1: 1$ million scale map, Bedrock Geology of Ireland.
The results for the artificial isotope caesium-137 $\left({ }^{137} \mathrm{Cs}\right)$ were generated by a modified process (Scheib and Beamish, 2010). ${ }^{137} \mathrm{Cs}$ has a half-life of approximately 30 years and a temporal correction was applied to the data to account for the six-year interval between the Tellus Border and Tellus and Cavan surveys.

\section{Results of the Tellus and Tellus Border airborne surveys}

Many published and unpublished reports describing different aspects of the results have been produced. For the Tellus survey of Northern Ireland these are summarised in Young and Donald (2013), with extensive references to previous work. A detailed technical analysis of the integrated Tellus and Tellus Border geophysical results has been presented by Hodgson and Ture (2014).

\section{Magnetic field}

The geological terranes and bedrock geology of the north of Ireland are shown in Figs 2.3 and 2.4. The TMI is shown in Fig. 2.5.

The most prominent magnetic signatures arise from the Antrim basalts (Antrim Lava Group), which are strongly magnetised with both positive and negative polarity. The magnetic imagery maps the extent of the basalts and structures within them. The major terrane 


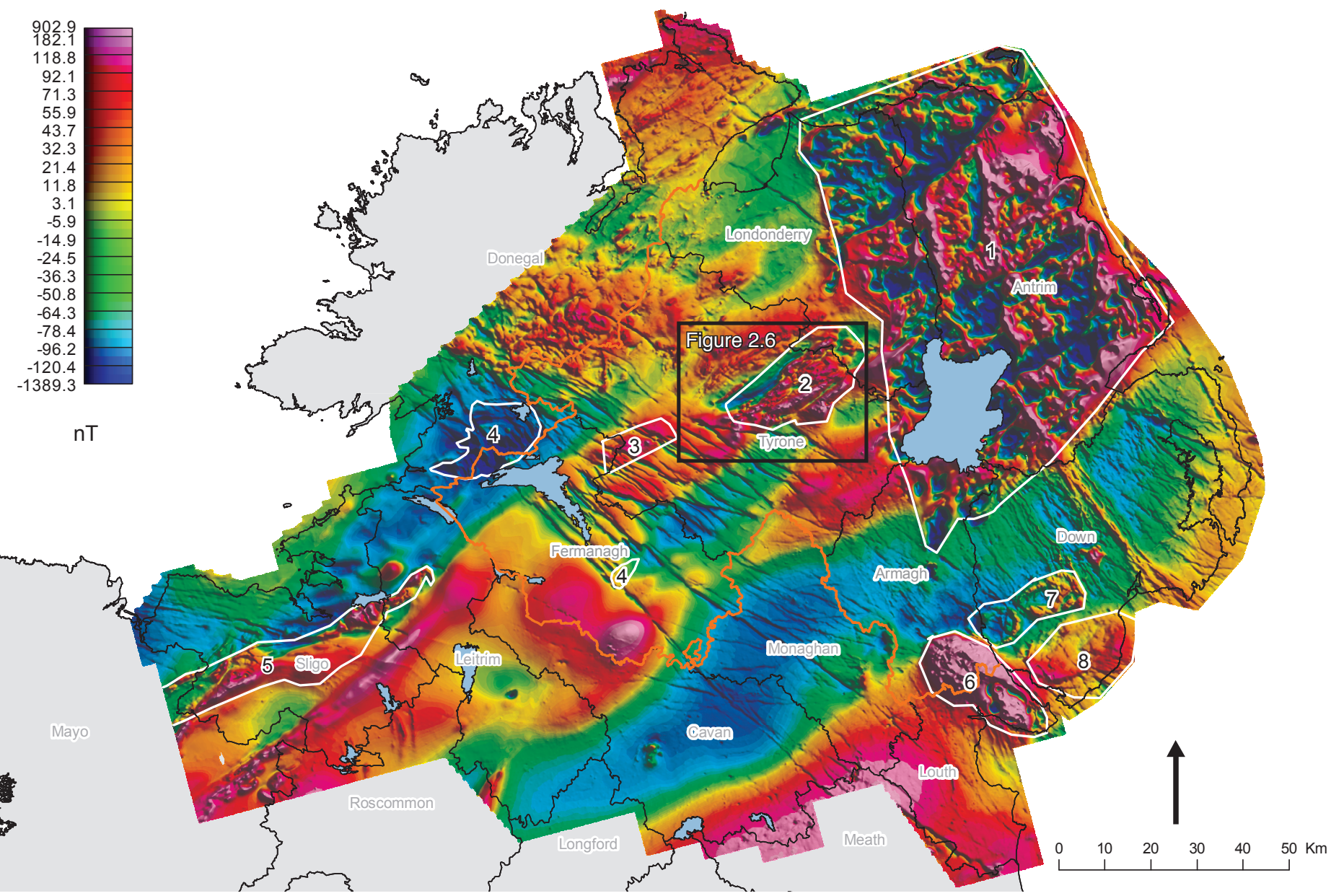

boundaries and lineaments associated with bounding faults of sedimentary basins have also been identified.

The Dalradian rocks in the north-west display high to intermediate magnetisation and prominent linear magnetic anomalies correspond with fold structures and magnetic marker horizons. Strong gradients within the Dalradian rocks of the Lough Derg Inlier, which comprise magnetite-rich metadolerite with some psammites and greenschists, outline rocks that may have mineralisation potential.

The margins and internal structures of the major intrusive centres of the Newry Igneous Complex, Mourne Mountains, Slieve Gullion, Barnesmore, Ox Mountains and the Carlingford Complex are delineated by clear magnetic intensity anomalies. In particular, the internal structure of the Tyrone Igneous Complex is revealed, with previously unmapped faults and sheared structures identified (Hollis et al., Chapter 12, this volume). These anomalies, too, indicate potentially mineralised zones within the Complex. Prominent circular or elliptical anomalies are also observed over the Palaeogene intrusions (Mourne Mountains, Slieve Gullion and Carlingford Complexes) and the Newry Igneous Complex, of Caledonian age. Structures and textures within these anomalies (visible at the large map scale) characterise different periods of intrusion or later cross-cutting relationships.

Strong magnetic gradients indicating possible changes in lithology are also observed over the Ox Mountains (Precambrian Terrane) and the Newry, Slieve Gullion and

Figure 2.5. Total Magnetic Intensity Anomaly (filtered by reduction-to-pole and upward continuation). Key: 1. Antrim Lava Group, 2. Tyrone Igneous Complex, 3. Lack Inlier, 4. Lough Derg Group, 5. Ox Mountains, 6. Slieve Gullion and Carlingford Complexes, 7. Newry Igneous Complex and 8. Mourne Mountains Complex (from Hodgson and Ture, 2014). 
Carlingford Complexes. Other areas of strong magnetic relief are observed in the southeast, over Silurian greywackes (possibly due to uplifted mafic basement controlled by a regional faulting) and over granitic intrusions.

\section{Dolerite dykes}

The region is characterised by several swarms of dolerite dykes, known from previous surveys (Gibson and Lyle, 1993), but shown in greater detail by the present work. These swarms are aligned in different orientations and the airborne anomalies range up to $500 \mathrm{~m}$ in width, because at the survey height the signals from groups of dykes are integrated. The dykes individually are typically 1-20 m wide. These dykes help to unravel the igneous history of the region and can be used to measure recent displacements along faults. They are also important in determining the regional stress fields at the time of emplacement.

Cooper et al. (2012) have identified four distinct dyke swarms, based on their orientation, relative age, density of distribution and remnant magnetic polarity, and estimated their ages relative to the principal intrusive centres and the deposition of the Antrim lavas. Two of the swarms appear to predate the deposition of the Antrim lavas and two appear to be intruded into them. The detailed magnetic mapping of the dyke swarms has allowed the measurement of strike-slip displacements along Cenozoic faults and provided information concerning tectonic stress and structural history (Anderson et al., Chapter 14, this volume).

\section{Magnetisation and mineralisation}

Magnetometer surveying is deployed widely in mineral exploration, for mapping regional structural architecture and for detailed mapping of faults, fractures and contacts that may indicate favourable locations for mineralisation at a local scale.

Arthurs and Earls (2004) have summarised the geological contexts of mineral exploration in Northern Ireland. The most prominent mineral exploration activity in the region in recent times has been for gold, in the Dalradian rocks of County Tyrone. A small gold mine operates at Cavanacaw, $5 \mathrm{~km}$ west of Omagh, and underground exploration is continuing at Curraginhalt, $5 \mathrm{~km}$ east of Gortin. Earls et al. (1989) recognised three prominent structural controls at Curraginhalt:

- the north-northeast trending Omagh Lineament, an alignment of gold and arsenic geochemical anomalies and vein orientations;

- the north-east trending Omagh Thrust Fault, which separates the Dalradian from the underlying Tyrone Igneous Complex (TIC). During the early to mid-Ordovician the Dalradian was thrust over the volcanic rocks of the TIC in a south-east direction;

- the west-northwest trending, north-dipping Curraghinalt Lateral Ramp. This is a positive relief structure developed within the TIC in the footwall of the 


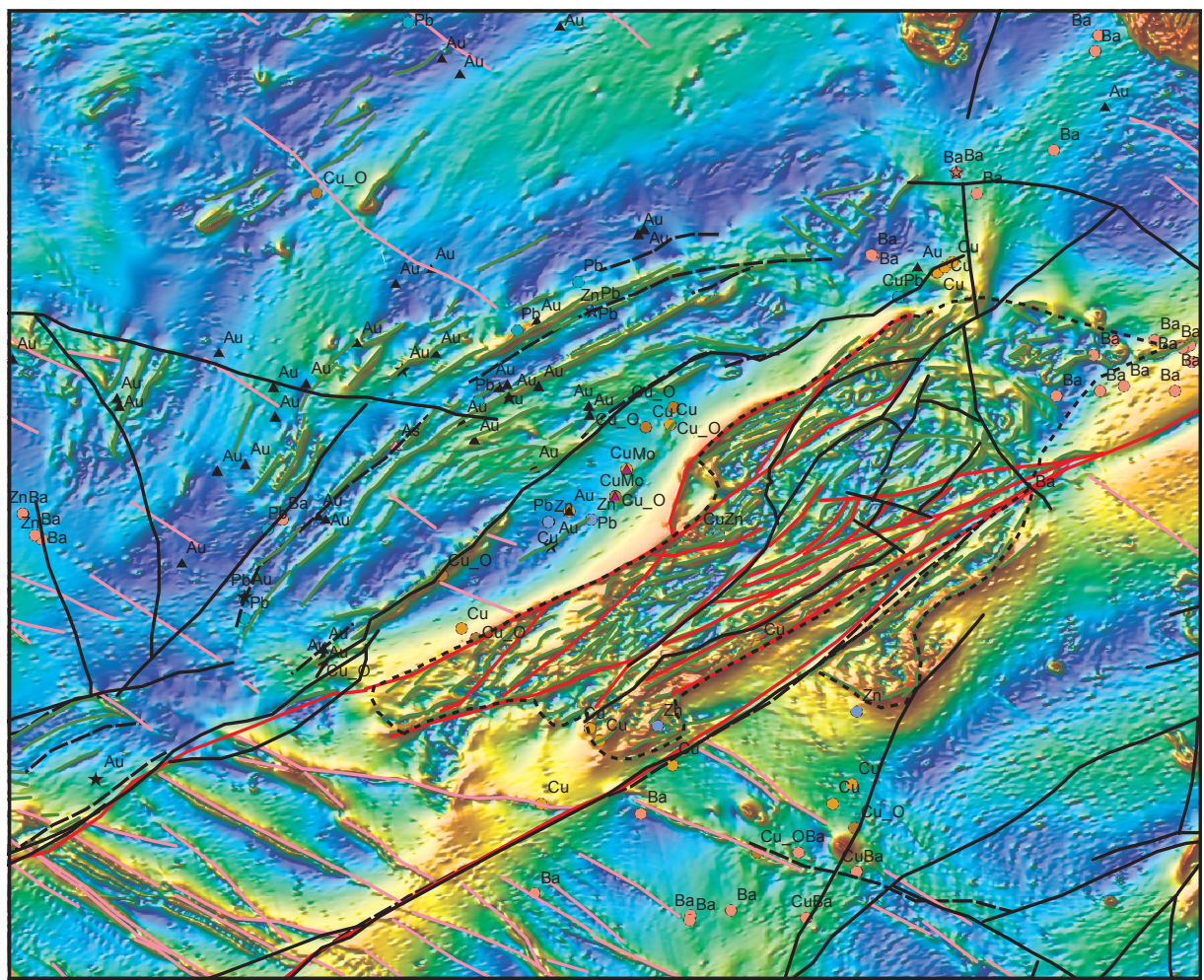

Omagh Thrust, which resulted in the formation of east-west oriented zones where mineralisation accommodated.

Magnetisation varies within the Dalradian and therefore the magnetic method is particularly useful for mapping such features. Structures in the north-east direction, broadly subparallel with the Omagh Thrust, are widely mapped north of the thrust, and several correspond with recorded mineralisation (Fig. 2.6).

The associations of the airborne magnetic results with known mineralisation in Dalradian rocks were examined by Hodgson and Ture (2013b). Within Dalradian rocks south of the Sperrin Mountains, magnetic anomalies highlight potential gold localities within a belt of low magnetic intensity at the contact between the Dart and Glenelly Formations. To the south of this line, mainly gold but also lead soil anomalies are mapped over four prominent acute magnetic linear highs within the outcrop of the Mullaghcarn Formation. Other sporadic gold occurrences also coincide with local magnetic gradients adjacent to the Omagh Thrust Fault and the trend extends as far as Cregganbaun, County Mayo.

Gold occurrences in the Dalradian rocks north of the Sperrin Mountains appear to align along an east-northeast trend concordant with the main Dalradian strike. Magnetic lineaments and EM conductors suggest a series of deep thrusts and shear zones, which have the potential to provide conduits for mineralisation.

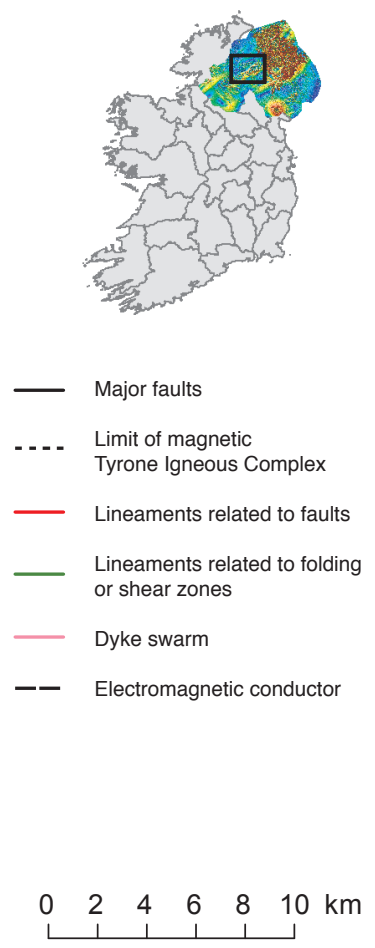

Figure 2.6. Magnetic pseudogravity horizontal gradient anomaly map of the Tyrone Igneous Complex and Dalradian rocks of County Tyrone with reported mineral localities (from Chacksfield, 2007). 
Lusty et al. (2009) used the statistical technique of fuzzy logic analysis on the County Tyrone Tellus airborne magnetic, EM and geochemical data, with gravity data and lineament data from geological mapping. This method of analysis allows consideration and prioritisation of targets according to the relative significance of various geological, geophysical and geochemical parameters, which are weighted according to their perceived importance. Several areas of increased prospectivity were identified, extending along and to the north of the Omagh Thrust.

Copper and lead mineralisation occurs between the Omagh Thrust Fault and the linear magnetic gradient marking the margin of the magnetic part of the Tyrone Igneous Complex. Two copper occurrences lie on the pronounced linear magnetic gradient over the Omagh Thrust Fault. There is also a cluster of copper anomalies over the thrust coincident with a local magnetic high over the north-east margin of the non-magnetic part of the Tyrone Igneous Complex.

Copper, lead and zinc occur in the non-magnetic Tyrone Volcanic Group and appear to be aligned with the magnetic gradient along the margin of the Tyrone Igneous Complex. Most localities lie along the north-western margin of the Laght Hill Tonalite. The copper and lead belt in this area lies in a broad magnetic low, with most deposits clustered within a subtle lineament within this zone.

Elsewhere, most notably the Ordovician-Silurian Longford-Down terrane hosts base metals which have been exploited since at least the 18th century and gold exploration is currently centred on the Clontibret deposit, County Monaghan and in adjacent south County Down. Lusty et al. (2012) have also applied the fuzzy logic approach using lineaments mapped by geophysics. Several prospective zones were identified, notably where regional strike-parallel structures and intersecting transverse faults intersect, and locations of probable anomalous stress which would be favourable for fluid flow and mineral deposition.

\section{Crystalline basement}

Magnetic data, particularly when used with gravity data, can help in estimation of gross sediment thickness overlying igneous or metamorphic basement, which is important information in the exploration for hydrocarbon and geothermal resources. Depth to crystalline basement can be derived by using appropriate digital filters of the magnetic data. By comparing the magnetic signature over known basement with that over covered areas, it is possible to make some estimate of the depth to basement and to map the boundaries of basement segments, or terranes.

After digital filtering, the magnetic field of the Midland Valley Terrane (Fig 2.3) shows as a broad positive magnetic high bounded to the north-west by the Tow Valley Fault and to the south-east along the margin of the low magnetic anomaly where magnetic basement is absent. Dominant geological structures relating to basement rocks (Fig 2.7) are observed oriented north-east-south-west and north-west-south-east at depths of about $3.5 \mathrm{~km}$. These structures can be interpreted as controlling lithological boundaries and 




are consistent with the regional north-east-south-west terrane boundary faults mapped at the surface. The presence of such orientations at $3.5 \mathrm{~km}$ depths may indicate the presence of Caledonian structures within basement rocks. The north-west-south-east trending structures are generally detached and displace the north-east-south-west oriented structures and lithologies. These north-west-south-east structures may indicate reactivated pre-Caledonian structures at this depth level. A strong magnetic signal is seen over the Belhavel Fault which runs through Carboniferous rocks in the south-west and may be due to uplifted basement rocks at depth.

\section{Electrical conductivity}

The apparent conductivity of rocks increases in proportion to their porosity, saturation, pore-water salinity, and sulphide and clay content. Airborne mapping of this parameter is a valuable means of geological mapping.

The apparent conductivity image (Fig. 2.8) reflects the general distribution of the major rock units and linear features/faults and at a fine scale maps many significant electrical conductors. Where overlain by thick younger conductive deposits (for example, lake sediments), the response from the bedrock geology is suppressed. Computed gradients of these data help to delineate geological structures and conductive marker zones, for example
Figure 2.7. Basement component of total magnetic intensity anomaly, after pole-reduction and upward continuation. North-east trending lines indicate terrane boundaries. Oblique lines are structures inferred from regional magnetic response. 


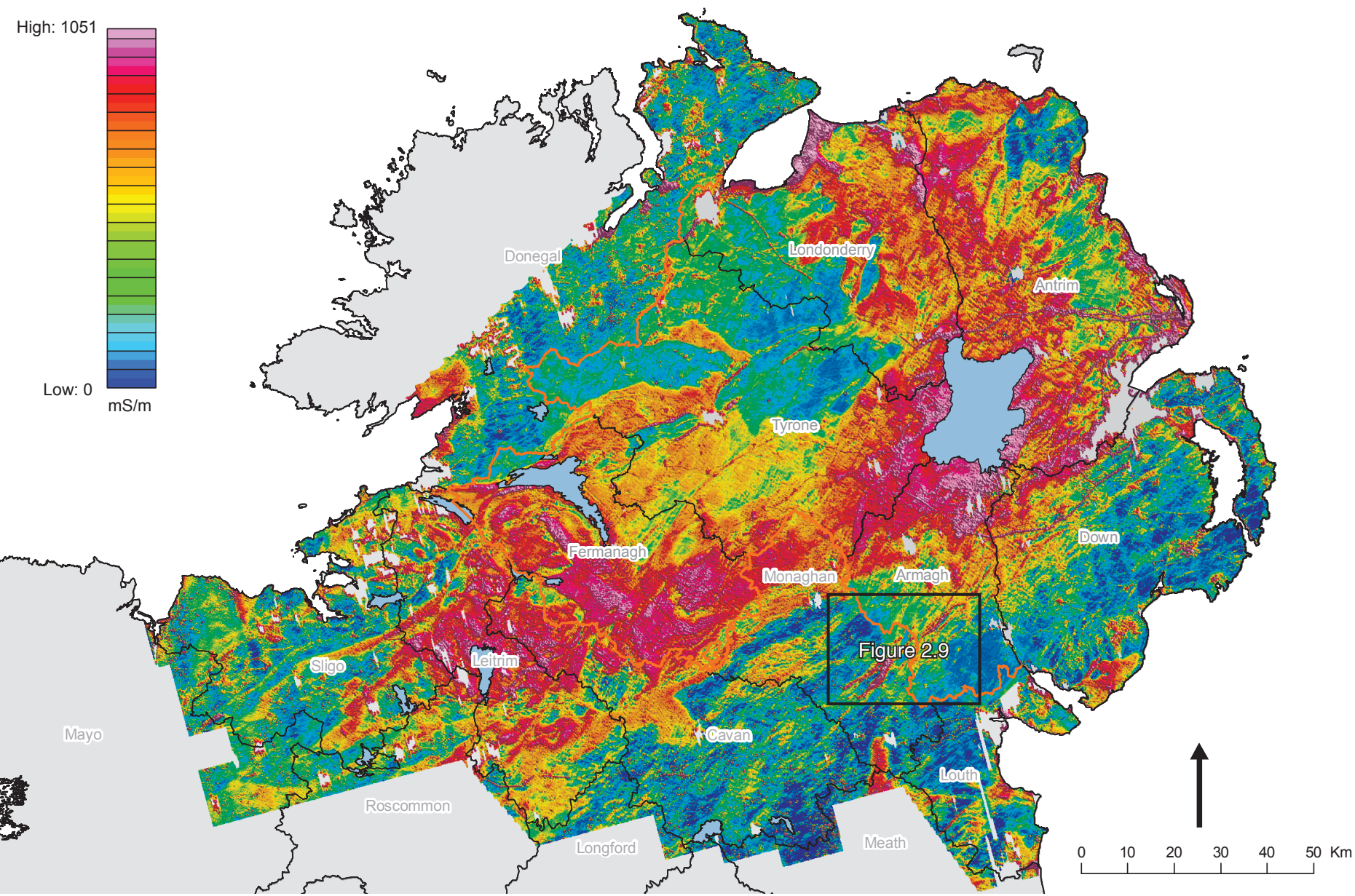

Figure 2.8. Filtered merged apparent conductivity data from low frequency $(3 \mathrm{kHz})$ airborne electromagnetic data. shale/clay-rich units within Carboniferous sequences that may be otherwise mapped as a single homogenous unit.

The oldest rocks of the region, the Dalradian Supergroup in the north-west and northeast, are characterised by relatively low conductivity (high resistivity). Distinct and isolated high-conductive areas are observed in places within Dalradian rocks associated with water bodies and linear structures. Dalradian psammites, pelites, gneisses and most schists are mostly resistive and typical of older, metamorphosed, harder rocks. Graphitic schists and shear zones along thrust faults display pronounced conductivity anomalies.

Across the region narrow lineaments, associated with some of the main geological terrane bounding faults, are clearly mapped. Many linear conductors are also associated with mineralisation observed in County Tyrone. Carboniferous shales and evaporites in counties Leitrim and Fermanagh and north County Cavan are also generally conductive. Relatively broader north-east-south-west trending, highly conductive EM anomalies extending through counties Sligo and Leitrim parallel with the Ox Mountains may indicate black shale horizons, with possible occurrence of graphite or possible hydrothermal alteration and basement uplift as indicated in magnetic data.

Ordovician greywackes of the Longford-Down terrane are generally resistive, but these beds enclose conductive north-easterly striking bands of the Moffat Shale Group (Beamish et al., 2010). These quasilinear conductors (Fig. 2.9) have helped to remap 


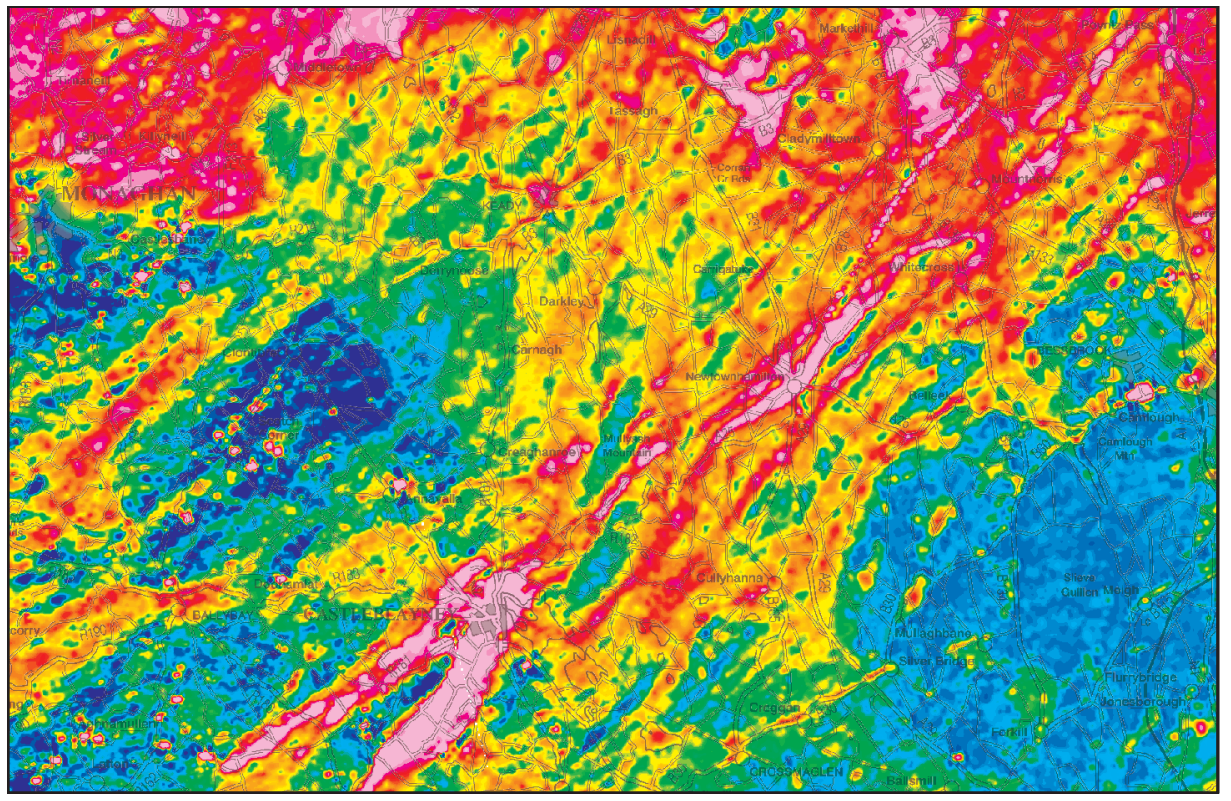

bedrock and to identify important markers in the geological sequence, with implications for gold mineralisation.

To the east, in counties Down and Louth, the Slieve Gullion and Carlingford complexes are generally resistive. Parts of the Mourne Mountains Complex are conductive, which may indicate deep weathering, saturated fractures or thick clay (glacial till) overburden.

The basalts of the Antrim Lava Group display high conductivity, particularly in the west, which may reflect an open pore structure, deep weathering or clay-filled amygdales in the lava flows. Higher conductivity could also reflect greater weathering on the western side. The eastern side is relatively resistive, indicating thinner clay cover or less weathering. High conductivity is also observed over Oligocene clay, sand and lignites of the Lough Neagh Group.

The difference in conductivity seen over different lakes reflects varying salinity or the nature of shallow sediments. Lough Neagh is shown to be more conductive than Lough Erne, suggesting that Lough Neagh may contain more dissolved salts or that the unconsolidated sedimentation under Lough Neagh is thicker. A number of borehole records around Lough Neagh show maximum sediment thickness of $489 \mathrm{~m}$ with an average of $150 \mathrm{~m}$.

Beamish (2013a) made a statistical comparison of the Tellus EM data with the lithologies mapped at the regional scale to generate a digital bedrock conductivity map, which is a valuable tool for assessing conductivity anomalies within different bedrock zones.

Anthropogenic responses, such as power-lines and roads, are widely seen. They are more visible in the low-frequency than in the higher frequency data. No major industrial pollution plumes are recognised at the regional scale, but local anomalies in the proximity

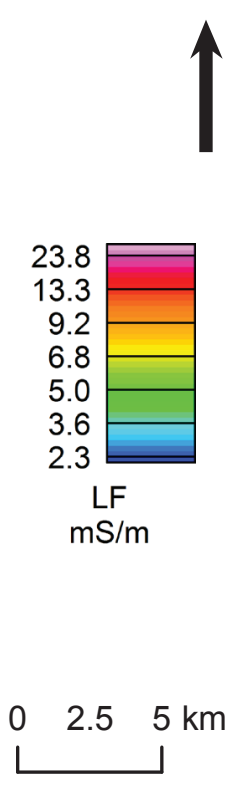

Figure 2.9. Apparent conductivity linear highs over Moffat Shales Group rocks within Lower Palaeozoic rocks in south Armagh and County Monaghan. For location see Fig. 2.8 
data have been used by Beamish (Chapter 18, this volume) to calculate radioactivity doserates and by Appleton and Hodgson (Chapter 20, this volume) to improve prediction of in-house radon levels in the region.

Granitic intrusions, notably the Mourne Mountain complex, show the highest radiometric levels of the region. Ordovician to Silurian rocks in the south-east are also relatively enriched in all three elements, as are Dalradian rocks to the north-west. At the other end of the scale, the Antrim Basalts in the north-east are characterised by low levels of natural occurring radioactivity.

Some formations are relatively enriched in one isotope. Potassium-enriched Permian to Triassic sediments are evident on the western margin of the Antrim Basalts and within the Lagan Valley. Potassium highs are also seen over K-feldspar-rich metasediments in the Ox Mountains as well as within felsites and granitites of the Mourne Mountains, Slieve Gullion, Barnesmore and Tullagh Point granites.

Predominantly uranium-enriched rocks occur within Carboniferous shales and limestones of the south-west. Concentrations of uranium are also found along the northern Sligo coastline, although this may be related to marine-derived sediments rather than the underlying geology.

In areas covered by soils produced by glacial action, the radiometric signals largely reflect the underlying bedrock. Tills and gravels derived from the granites and from the Lower Palaeozoic rocks display the highest values for all three elements. The lowest measured values correspond to peat. Sandstone also exhibits relatively low values, particularly for thorium and uranium. In general, potassium and thorium show very similar trends for the different subsoil units. Strong uranium signals are associated with till derived from Carboniferous limestone and shale but are not matched by corresponding increases in potassium or thorium.

Understanding the bedrock provenance of soils is important in mineral prospecting. These results indicate that the soil and till units have not been transported far from the underlying rocks from which they evolved. This suggests a limited glacial movement of these soils. The extent to which glacially scoured material has moved is illustrated by the results around the Tardree Rhyolite Complex (north-east of Lough Neagh, Fig. 2.10), from which a smear of elevated potassium-rich debris extends in a north-westerly direction.

Over parts of the region gamma radiation is attenuated by overlying screening material such as water or peat. Research into the extent to which these data can be used for mapping peat distribution and thickness has been described by Beamish (2013b, 2014). Keaney et al. (2013) describe a GIS-based study comparing the radioactivity measurements with known peat depths. In an innovative application, Rawlins et al. (2009) correlated the potassium signal of the airborne gamma-ray survey with loss-on-ignition from the Tellus soil geochemistry survey to improve estimation of carbon in soil.

Locally isolated man-made radioactivity anomalies are observed over quarries and landfills, where soil has been stripped off and construction material dumped. On a regional 
scale the results have demonstrated how anthropogenic radioactivity has been distributed widely over the north of Ireland by fallout from nuclear weapons testing and from the 1986 Chernobyl accident (Scheib and Beamish, 2010; Rawlins et al., 2011; Beamish, Chapter 18, this volume).

\section{Conclusions}

The two Tellus airborne surveys were completed on schedule and within budget and resulted in the largest contiguous area of high-resolution digital geophysical data produced in the UK and Ireland to date. The new maps and high-resolution imagery reveal details of concealed geological structures for the first time. These results enhance our understanding of the geological history of Ireland, contribute to exploration for natural resources, and provide baseline data for the sustainable management of our environment.

\section{ACKNOWLEDGEMENTS}

This chapter is published with the permission of the Director of the Geological Survey of Ireland and the Executive Director of the British Geological Survey (NERC).

\section{REFERENCES}

Arthurs, J. and Earls, G., 2004 'Minerals', in W.I. Mitchell (ed.), The Geology of Northern Ireland: Our Natural Foundation (2nd edition). Belfast. Geological Survey of Northern Ireland.

Beamish, D., 2013a 'The bedrock electrical conductivity structure of Northern Ireland', Geophysical Journal International, 194, 683-99. Available at http://nora.nerc.ac.uk/502882/.

Beamish, D., 2013b 'Gamma ray attenuation in the soils of Northern Ireland, with special reference to peat', Journal of Environmental Radioactivity, 115, 13-27. Available at http://nora.nerc.ac.uk/500308/.

Beamish, D., 2014 'Peat mapping associations of airborne radiometric survey data', Remote Sensing, 6, 1, 521-39. Available at http://nora.nerc.ac.uk/506700/.

Beamish, D., Cuss, R.J. and Lahti, M., 2006a 'The Tellus airborne geophysical survey of Northern Ireland: Phase 1 Logistics report', British Geological Survey Technical Report IR/06/032. Keyworth, UK. Available at http://nora.nerc.ac.uk/7184/.

Beamish, D., Cuss, R.J. and Lahti, M., 2006b 'The Tellus airborne geophysical survey of Northern Ireland: Phase 2 Logistics report', British Geological Survey Technical Report IR/06/104. Keyworth, UK.

Beamish, D., Cuss, R.J., Lahti, M., Scheib, C. and Tartaras, E., 2006c 'The Tellus Airborne Geophysical Survey of Northern Ireland: Final Processing Report', British Geological Survey Technical Report IR/06/136. Keyworth, UK. Available at http://nora.nerc.ac.uk/7427/.

Beamish, D., Kimbell, G.S., Stone, P. and Anderson, T.B., 2010 'Regional conductivity data used to reassess Early Palaeozoic structure in the Northern Ireland sector of the Southern Uplands-Down-Longford terrane', Journal of the Geological Society, 167, 4, 649-57. Available at http://nora.nerc.ac.uk/10070/.

Carruthers, R.M., Beamish, D., Heaven, R.E., Legg, I.C., Mitchell, W.I., Reay, D.M. and Walker, A.S.D., 1999 'Regional interpretation of gravity and aeromagnetic data from Northern Ireland', British Geological Survey Technical Report WK/96/05C. Keyworth, UK.

Chacksfield, B., 2007 'A preliminary interpretation of Tellus airborne magnetic and electromagnetic data for Northern Ireland', British Geological Survey Internal Report IR/07/041. Keyworth, UK. 


\section{Hodgson and Young}

Cooper, M.R., Anderson, H., Walsh, J.J., van Dam, C. L., Young, M. E., Earls, G. and Walker, A. S. D., 2012 'Palaeogene Alpine tectonics and Icelandic plume-related magmatism and deformation in Ireland', Journal of the Geological Society, London, 169, 29-36. Available at http://nora.nerc.ac.uk/16421/.

Dardis, O., 2002 Airborne Geophysical Surveying in Ireland: The Current Status, Dublin. Exploration and Mining Division, Department of Communications, Marine and Natural Resources. Available at http://www.mineralsireland.ie/Publications+Archive.htm.

Earls, G., Clifford, J.A. and Meldrum, A., 1989 'The Curraghinalt Gold Deposit, County Tyrone, Northern Ireland', Transactions of the Institution of Mining and Metallurgy (Section B, Applied Earth Science), 98, B50-1.

Geological Survey of Ireland, 2014 Bedrock Geology of Ireland, 1:1,000,000 Scale (map). Dublin.

Gibson, P.J. and Lyle, P., 1993 'Evidence for a major Tertiary dyke swarm in County Fermanagh, Northern Ireland, on digitally processed aeromagnetic imagery', Journal of the Geological Society, $150,37-8$.

Hautaniemi, H., Kurimo, M., Multala, J. Leväniemi, H. and Vironmäki, J., 2005 'The "three in one" aerogeophysical concept of GTK in 2004', in M.-L. Airo (ed.), Aerogeophysics in Finland 1972-2004: Methods, System Characteristics and Applications. Special Paper 39, 21-74. Espoo, Finland. GTK: Geological Survey of Finland.

Hodgson, J.A. and Ture, M.D., 2013a Tellus Border Airborne Geophysics Logistics Report Version 3, Geological Survey of Ireland/Geological Survey of Northern Ireland joint report. Available at http://www.tellusborder.eu/Library.htm.

Hodgson, J.A. and Ture, M.D., 2013b Tellus Border Airborne Geophysics Data Processing Report Version 2. Geological Survey of Ireland/Geological Survey of Northern Ireland joint report. http://www.tellusborder.eu/Library.htm

Hodgson, J.A. and Ture, M.D., 2014 Tellus Border Project Airborne Geophysical Interpretation Report. Geological Survey of Ireland and Geological Survey of Northern Ireland Joint Report. Available at http://www.tellusborder.eu/Library.htm.

Jones, D.G. and Scheib, C. 2007 A Preliminary Interpretation of Tellus Airborne Radiometric Data. British Geological Survey Commissioned Report, CR/07/061N. Keyworth, UK. Available at http://nora.nerc.ac.uk/16872/.

Keaney, A., McKinley, J., Graham, C., Robinson, M. and Ruffell, A., 2013 'Spatial statistics to estimate peat thickness using airborne radiometric data', Spatial Statistics, 5, 3-24.

Lahti, M., Beamish, D., Cuss, R.J. and Williams, J., 2007 'Deculturing of the Northern Ireland Tellus magnetic data', British Geological Survey Internal Report IR/07/147. Keyworth, UK. Available at http://nora.nerc.ac.uk/7570/.

Leväniemi, H., Beamish, D., Hautaniemi, H., Kurimo, M., Suppala, I., Vironmaki, J., Cuss, R. J., Lahti, M. and Tartaras, E., 2009 'The JAC airborne EM system: AEM-05', Journal of Applied Geophysics, 67, 219-33. Available at http://nora.nerc.ac.uk/7410/.

Lusty, P.A.J., Gunn, A.G., McDonnell, P.M., Chacksfield, B.C., Cooper, M.R. and Earls, G., 2009 'Gold potential of the Dalradian rocks of north-west Northern Ireland: prospectivity analysis using Tellus data', Transactions of the Institution of Mining and Metallurgy (Section B, Applied Earth Science), 118, B162-77. Available at http://nora.nerc.ac.uk/9542/.

Lusty, P.A.J., Scheib, C., Gunn, A.G. and Walker, A.S.D., 2012 'Reconnaissance-scale prospectivity analysis for gold mineralisation in the Southern Uplands-Down-Longford Terrane, Northern Ireland', Natural Resources Research, 21, 359-82. Available at http://nora.nerc.ac.uk/18864/.

Mitchell, W.I. (ed.), 2004 The Geology of Northern Ireland: Our Natural Foundation (2nd edition). Belfast. Geological Survey of Northern Ireland.

Rawlins, B.G., Marchant, B.P., Smyth, D., Scheib, C., Lark, R.M. and Jordan, C., 2009 'Airborne radiometric survey data and a DTM as covariates for regional scale mapping of soil organic carbon across Northern Ireland', European Journal of Soil Science, 60, 44-54. Available at http://nora.nerc.ac.uk/5755/. 
Rawlins, B.G., Scheib, C., Beamish, D., Webster, R., Tyler, A.N. and Young, M.E., 2011 'Landscape-scale controls on the spatial distribution of caesium 137: a study based on an airborne geophysical survey across Northern Ireland', Earth Surface Processes and Landforms, 36, 2, 158-69. Available at http://nora.nerc.ac.uk/13300/.

Reay, D.M., 2004 'Geophysics and concealed geology', in W.I. Mitchell (ed.), The Geology of Northern Ireland: Our Natural Foundation (2nd edition). Belfast. Geological Survey of Northern Ireland.

Scheib, C. and Beamish, D., 2010 'High spatial resolution observations of ${ }^{137} \mathrm{Cs}$ in northern Britain and Ireland from airborne geophysical survey', Journal of Environmental Radioactivity, 101, 9, 670-80. Available at http://nora.nerc.ac.uk/12929.

White, J.C. and Beamish, D., 2015 'Levelling aeromagnetic survey data without the need for tielines', Geophysical Prospecting, 63, 2, 451-60. Available at http://nora.nerc.ac.uk/509156/.

Young, M.E. and Donald, A.W. (eds), 2013 A Guide to the Tellus Data. Belfast. Geological Survey of Northern Ireland. Available at http://nora.nerc.ac.uk/509171/. 
Unearthed: impacts of the Tellus surveys of the north of Ireland

First published in 2016 by the

Royal Irish Academy

19 Dawson Street

Dublin 2

www.ria.ie

Copyright (C) 2016 Royal Irish Academy

ISBN: 978-1-908996-88-6

The articles in this book are open access and distributed under the terms of the Creative Commons Attribution 4.0 licence, which permits unrestricted use, distribution and reproduction in any medium, provided the original authors and source are credited. To view a copy of this licence, visit https://creativecommons.org/licenses/by/4.0/

Except where noted:

Geological mapping for Northern Ireland / Tellus data are provided by the Geological Survey of Northern Ireland.

Geological mapping for Ireland / Tellus Border data are provided by the Geological Survey of Ireland.

Topographic mapping for Northern Ireland is derived from Land and Propery Services Open Data and contains public sector information licensed under the Open Government Licence v3.0. (http://www.nationalarchives.gov.uk/doc/open-governmentlicence/version/3/).

Topographic mapping for Ireland is derived from Ordnance Survey of Ireland Open Data (https://creativecommons.org/licenses/by/4.0/legalcode).

While every effort has been made to contact and obtain permission from holders of copyright, if any involuntary infringement of copyright has occurred, sincere apologies are offered, and the owner of such copyright is requested to contact the publisher.

British Library Cataloguing-in-Publication Data. A catalogue record is available from the British Library.

Design: Alex Donald, Geological Survey of Northern Ireland.

Index: Brendan O'Brien.

Printed in Poland by L\&C Printing Group. 


\section{Table of Contents:}

\section{Prelim}

DOI: https://doi.org/10.7486/DRI.b851k323d

\section{Chapter 1}

The Tellus geosciences surveys of the north of Ireland: context, delivery and impacts

DOI: https://doi.org/10.7486/DRI.st74s528d

\section{Chapter 2}

The Tellus airborne geophysical surveys and results DOI: https://doi.org/10.7486/DRI.t148tx96z

\section{Chapter 3}

The Tellus geochemical surveys, results and applications

DOI: https://doi.org/10.7486/DRI.t722wq645

\section{Chapter 4}

Stakeholder engagement for regional geoscientific surveying: the Tellus Border communications campaign

DOI: https://doi.org/10.7486/DRI.w089fr763

\section{Chapter 5}

Mineral resources and Tellus: the essential balance DOI: https://doi.org/10.7486/DRI.wd37kb12s

\section{Chapter 6}

Gold exploration in the north of Ireland: new targets from the Tellus Projects

DOI: https://doi.org/10.7486/DRI.wh24m696v

\section{Chapter 7}

Using soil geochemistry to investigate gold and base metal distribution and dispersal in the glaciated north of Ireland

DOI: https://doi.org/10.7486/DRI.wm11n3806

\section{Chapter 8}

Critical metals for hightechnology applications: mineral exploration potential in the north of Ireland DOI: https://doi.org/10.7486/DRI.wp98p0649

\section{Chapter 9}

A natural laboratory for critical metals investigations in the Mourne Mountains granites

DOI: https://doi.org/10.7486/DRI.cc08ww45f

\section{Chapter 10}

Geothermal potential of granitic rocks of the Mourne Mountains

DOI: https://doi.org/10.7486/DRI.ff36jm09f

\section{Chapter 11}

Shape and intrusion history of the Late Caledonian

Newry Igneous Complex, Northern Ireland

DOI: https://doi.org/10.7486/DRI.2v248822m

\section{Chapter 12}

Using Tellus data to enhance targeting of volcanogenic massive sulphide mineralisation in the Tyrone Igneous Complex

DOI: https://doi.org/10.7486/DRI.5x226w262

\section{Chapter 13}

The geological significance of electrical conductivity anomalies of the Ordovician- Silurian Moffat Shale Group, Northern Ireland

DOI: https://doi.org/10.7486/DRI.6m31f4149

\section{Chapter 14}

Faults, intrusions and flood basalts: the Cenozoic structure of the north of Ireland

DOI: https://doi.org/10.7486/DRI.90205h306

\section{Chapter 15}

Information for agriculture from regional geochemical surveys: the example of soil $\mathrm{pH}$ in the Tellus and Tellus Border data

DOI: https://doi.org/10.7486/DRI.dv14c8060

\section{Chapter 16}

An ecohydrological investigation of wetlands in the border counties of Ireland: a framework for a holistic understanding of wetland systems DOI: https://doi.org/10.7486/DRI.hd775d90j 
Chapter 17

Assessing nutrient enrichment risk to groundwaterdependent ecosystems in the border counties of Ireland DOI: https://doi.org/10.7486/DRI.k356pk18j

\section{Chapter 18}

Mapping the terrestrial gamma radiation dose

DOI: https://doi.org/10.7486/DRI.k930rb86z

\section{Chapter 19}

Soils and their radiometric characteristics

DOI: https://doi.org/10.7486/DRI.mp495t62g

\section{Chapter 20}

Modelling in-house radon potential using Tellus data and geology to supplement inhouse radon measurements

DOI: https://doi.org/10.7486/DRI.ns06hm86z

\section{Chapter 21}

Determining geochemical threshold values from the Tellus data sets: the examples of zinc and iodine| DOI: https://doi.org/10.7486/DRI.r2087418g

\section{Chapter 22}

Identification of the geochemical signatures of diffuse pollution in the Tellus Border soil data set, using source apportionment

DOI: https://doi.org/10.7486/DRI.wh24m698d

\section{Chapter 23}

Stream sediment background concentrations in mineralised catchments in Northern Ireland: assessment of 'pressures' on water bodies in fulfilment of Water Framework Directive objectives DOI: https://doi.org/10.7486/DRI.x633tf86g

\section{Chapter 24}

Mapping metallic contamination of soils in the Lower Foyle catchment

DOI: https://doi.org/10.7486/DRI.9k42bv355

\section{Chapter 25}

Refining the human health risk assessment process in Northern Ireland through the use of oral bioaccessibility data

DOI: https://doi.org/10.7486/DRI.9p29cr199

\section{Chapter 26}

Combining environmental and medical data sets to explore potential associations between environmental factors and health: policy implications for human health risk assessments

DOI: https://doi.org/10.7486/DRI.9s16dn03n

\section{Chapter 27}

Mapping a waste disposal site using Tellus airborne geophysical data

DOI: https://doi.org/10.7486/DRI.9w03fh87q

\section{Chapter 28}

The use of aero-magnetics to enhance a numerical groundwater model of the Lagan Valley aquifer, Northern Ireland

DOI: https://doi.org/10.7486/DRI.9z90gd711

\section{Chapter 29}

Carbon sequestration in the soils of Northern Ireland: potential based on mineralogical controls DOI: https://doi.org/10.7486/DRI.b277h9556

\section{Chapter 30}

Spatial distribution of soil geochemistry in geoforensics DOI: https://doi.org/10.7486/DRI.b564j6392

\section{End matter}

DOI: https://doi.org/10.7486/DRI.bc38m007j 